\title{
NOTES ON THE RUSSIAN ENDEMIC ANT GENUS AULACOPONE ARNOLDI (HYMENOPTERA: FORMICIDAE)*
}

\author{
By ROBERT W. TAYLOR \\ Australian National Insect Collection \\ CSIRO, Division of Entomology \\ P. O. Box 1700, Canberra City, A.C.T. \\ Australia
}

\section{INTRODUCTION}

The ponerine ant genus Aulacopone, and its only known species $A$. relicta, were described by Arnoldi (1930) from a unique dealate female collected at Alazapin, near Lenkoran ( $38^{\circ} 45^{\prime} \mathrm{N}$., $48^{\circ} 50^{\prime} \mathrm{E}$.), in Azerbaydzhan S.S.R., near its border with Iran. The specimen was taken in galleries of the formicine ant Lasius emarginatus (Olivier), under the bark of an oak stump, in Talisch mid-montane forest. The holotype, which I have not seen, is reportedly in the collection of the Zoological Institute, Leningrad. A second, previously unreported dealate female of $A$. relicta, now in the Arnoldi collection at the Institute of Evolutionary Animal Morphology, Moscow, was taken by Arnoldi on Mt. Gugljaband, near Alekseevka, Azerbaydzhan, in 1936. The only important reference to this species, apart from Arnoldi's paper, is in Brown's (1958a) reclassification of tribe Ectatommini. These articles by Arnoldi and Brown are essential references to this paper.

Aulacopone is the only extant genus of subfamily Ponerinae with known distribution limited to some part of Holarctica. In addition it is one of only two ant genera known exclusively from the Soviet Union, the other being Rossomyrmex Arnoldi (subfamily Formicinae).

Following a recent visit to Moscow (under the Australia/U.S.S.R. Science Exchange Agreement) I was permitted by Dr. Arnoldi and Dr. A. A. Zakharov to carry the over-glued Mt. Gugljaband specimen to Australia on loan, there to re-mount, clean and prepare it for examination by scanning electron microscopy. This paper is the result. The general accuracy of Arnoldi's original description is con-

*Manuscript received by the editor April 18, 1980 
firmed and some additional features are described, though the risk of damage to the specimen precluded dissection of its mouthparts or sting. The relationship of Aulacopone to Heteroponera Mayr, suggested by Brown, is supported. This has interesting evolutionary and biogeographical implications.

\section{TAXoNomic and BIOGEOGRAPHic Relationships of AULACOPONE}

The allocation of Aulacopone to tribe Ectatommini is unquestionable, and is further supported by the absence of arolia from the tarsi of the available specimen. Within subfamily Ponerinae the absence of arolia is apparently unique to species of tribe Ectatommini, except Paraponera clavata (Fabricius) (J. Freeland and R. D. Crozier, pers. comm.).

In order to understand in modern terms Arnoldi's discussion on the possible affinities of Aulacopone, the following synonymies by Brown are relevant: Gnamptogenys Roger $=$ Alfaria Emery $=$ Stictoponera Mayr; Proceratium Roger $=$ Sysphincta Mayr; Ectatom$\operatorname{mini}=$ Proceratiini $=$ Stictoponerini. ${ }^{*}$

Arnoldi considered Aulacopone close to Gnamptogenys, a genus of somewhat diverse content now strongly and disjunctly represented (a) in the Indo-Australian area (from Ceylon and Western China to the Philippines and Fiji, with one New Guinean species on far northern Cape York Peninsula providing the only known Australian records), and (b) in the New World (from Texas south to Tucumán and Buenos Aires, including the Antilles and Peru, but as yet not Chile). The genus is not known from Africa. Brown recognised 26 Indo-Australian species, and more are now known. Sixty-four neotropical species were listed by Kempf (1972). One extinct species, $G$. europaeum (Mayr), is known from Oligocene Baltic Amber, and according to Brown, Archiponera wheeleri Carpenter, of the North American Oligocene Florissant Shale, seems close to Gnamptogenys. Arnoldi indicated specific resemblances between Aulacopone and the palaeogean "Stictoponera" and neogean "Alfaria" species groups of Brown's Gnamptogenys classification. He considered these three taxa, comprising his spurious subtribe Stictoponerini, to represent a

*The name Stictoponerini was proposed by Arnoldi (1930); it seems not to have been used subsequently, or formally synonymized under Ectatommini, where it belongs following Brown's reclassification. 
"grade" standing parallel to Proceratium in ectatommine evolution, especially to those species then assigned to Sysphincta.

Brown, however, related Aulacopone to Heteroponera, a genus which has its distribution somewhat more peripheral to the main northern continents than that of Gnamptogenys, especially in the Old World. There are two faunistic elements : one in eastern and southwestern mainland Australia, Tasmania and New Zealand; the other in South America, from Panama south to Uruguay and Chile (Kempf and Brown 1968). Heteroponera is unknown from the Palearctic, Oriental and Ethiopian regions, or from Melanesia. It has no known fossil record. Undescribed species known from Australia could at least treble its continental fauna of three species recognised by Brown, and the name $H$. imbellis (Emery), as applied by Brown, certainly refers to a partly intractable complex of several Australian species. New Zealand has a single known endemic species. Kempf (1972) listed 13 Neotropical species.

The Aulacopone female (Figs. 1-4) is very like her counterparts in species of the Heteroponera imbellis complex, in size, general habitus, structure of the mesosoma, and colour. Aulacopone and Heteroponera share several major features distinguishing them from Gnamptogenys, including the presence of a median longitudinal costa, distinct from other sculpture, on the head (terminating in front of the anterior ocellus in females), and the absence of a tooth or spine on the upper surface of each posterior coxa (a feature of almost all Gnamptogenys species, found nowhere else among the Ectatommini). Aulacopone also shares with Heteroponera those features distinguishing the latter from the neotropical genus Acanthoponera; these include the absence of long propodeal spines and a strong tooth or spine on the petiolar summit, and the lack of a prominent basal lobe accompanying a distinct submedian tooth on each tarsal claw. Basal lobes are characteristic of Acanthoponera. Submedian teeth are vestigially represented on the claws of some neotropical Heteroponera species, though they are lacking from all Australian species, and from Aulacopone. The lack of submedian teeth on the tarsal claws also distinguishes Aulacopone and Heteroponera from the prominent and diverse Australia-based genus Rhytidoponera, the species of which, in addition, almost all have a strong tooth-like process on each lateral pronotal margin. Such structures are lacking in other ectatommine genera, including Aulacopone, and all Hete- 
roponera species except $H$. relicta (Wheeler). The latter could stand close to the Rhytidoponera ancestry.

Aulacopone resembles Heteroponera in all fundamental structural details referred to in Brown's discussion of features diagnosing or characterising ectatommine genera, except those related to cranial and petiolar structure, and other minor features, as detailed below.

In discussing likely relationships among the ectatommine genera Brown considered Acanthoponera to be "the genus surviving with the greatest number of primitive characters". Heteroponera was considered "a rather conservative stock" that "can be derived directly from Acanthoponera", and Rhytidoponera was represented as a genus "very closely related to Heteroponera" which "may have originated in the Australian region from some Heteroponera-like stock". According to Brown these genera stand apart as a lineage separate from that of the exclusively neotropical genera Ectatomma Fr. Smith and Paraponera Fr. Smith. Gnamptogenys, while difficult to relate precisely to other genera, "seems closer to the Acanthoponera/Heteroponera line than to Ectatomma". All the above genera are essentially epigaeic, in contrast to the two further ectatommine genera, Proceratium Roger and Discothyrea Roger, which are cryptobiotic and "seem, on the basis of adult characters, to be closest to Heteroponera", while "the Baltic Amber species Bradoponera meieri (Mayr) looks like a reasonable step in this line".

Workers of Proceratium and Discothyrea are notable for their possession of cryptobiotic attributes, including medium to small size, with relatively small eyes, reduced sculpture and pilosity, and depigmented coloration. In particular the mesosomal structure is streamlined, through ankylosis of its component sclerites, and the frontoclypeal structure is highly modified. The antennal sockets are exposed in full-face view, through elevation of the lobes of the frontal carinae, and they have migrated anteromedially, carrying the clypeus and frontal area forwards to form a shelf-like process over the mandibles. This is especially prominent in Discothyrea, which usually has an erect vertical plate separating the antennal sockets, a structure which in some species is " $\mathrm{T}$ " shaped in transverse section and extends back along the head to enclose an antennal scrobe on each side, usually accompanied by a weak parallel longitudinal concavity of the frons. Both Proceratium and Discothyrea have their tubulate abdominal segment IV reflexed downwards or forwards under the body, a characteristic shared with various Heteroponera 

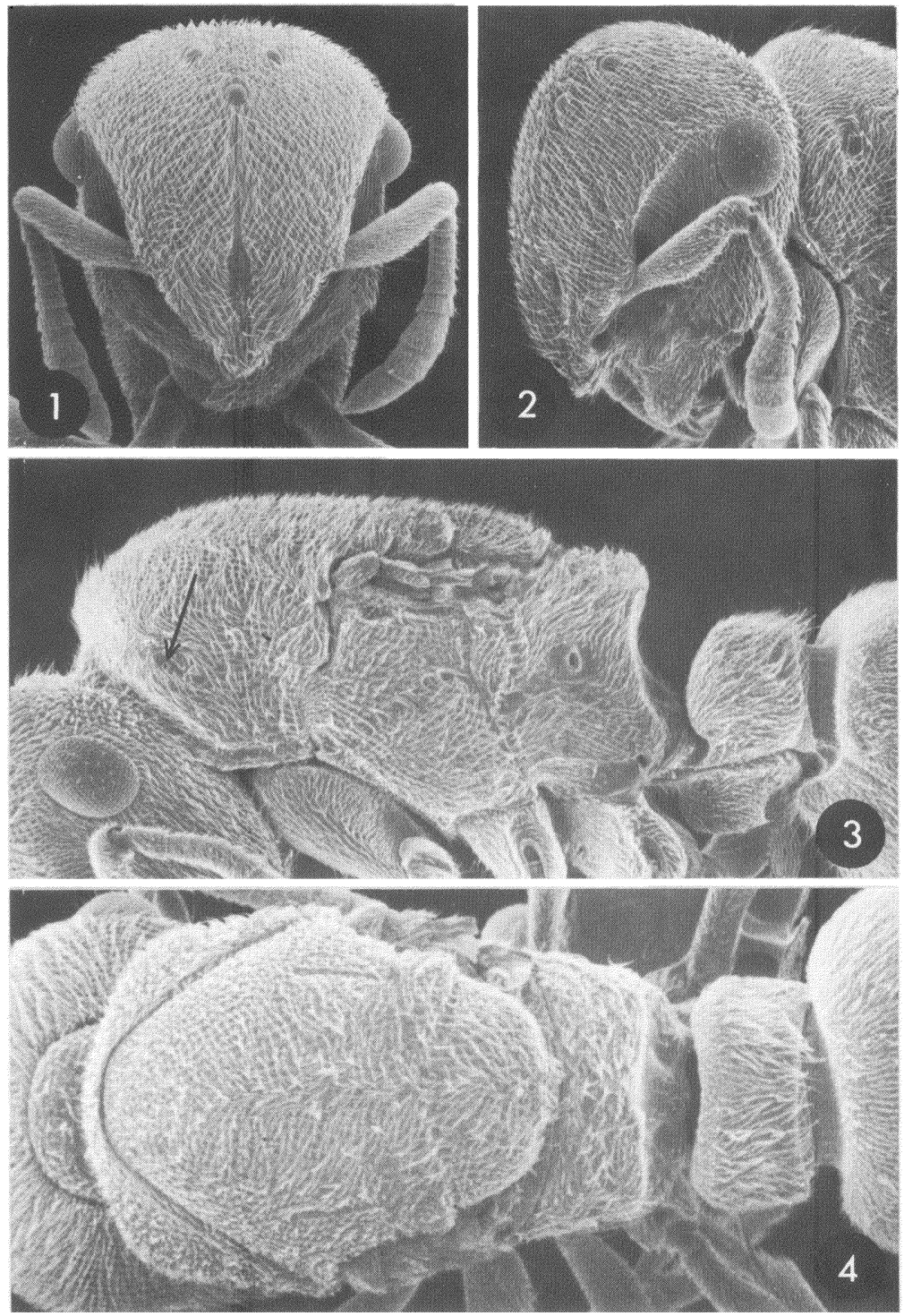

Figures 1-4. Aulacopone relicta, female, Mt Gugljaband, Azerbaydzhan. Fig. 1, head, full-face view. Fig. 2, Head, oblique frontal view. Fig. 3, mesosoma and petiole, lateral view (position of humeral pits indicated by arrow). Fig. 4, mesosoma and petiole, dorsal view. Scanning electron micrographs; see text for dimensions. 
species and with Bradoponera. In some Discothyrea species, in particular, the petiole is transverse in dorsal view and only slightly constricted behind, at its articulation with the following (postpetiolar) abdominal segment. These attributes are doubtless adaptations to life in confined moist and irregular spaces in soil or rotting wood, where effective use of the antennae and sting would otherwise be compromised. The clypeal shelf probably functions wih the mandibles to aid transport of arthropod eggs, upon which several species of both genera (including the remarkable secondarily epigaeic Mauritian Proceratium avium Brown) are known to feed (Brown 1958b, 1974). Females generally resemble workers, though the eyes are usually less reduced, and the mesosoma non-ankylosed, at least in those species with winged gynes.

The structural features of Aulacopone are, of course, known only for the female; those of the worker must be surmised. A. relicta nonetheless shows clear cryptobiotic tendencies. The female is of small to medium size for an ectatommine*, with fine sculpture comparable to that of various Proceratium and Discothyrea species, and relatively pale yellowish brown colour. The pilosity is dense, though short and not unlike that of some Discothyrea species, and the eyes are smaller than would be expected in an epigaeic ectatommine. The really distinctive features of the genus have to do with its cephalic structure (Figs. 1, 2), in which the fronto-clypeal part of the head is extended forwards to form a strong triangular process, partly covering the closed mandibles. The antennal fossae are carried forwards on this process almost to the level of the mandibular bases. The resulting structure is, however, very different from that of any Proceratium or Discothyrea species, for here the lobes of the frontal carinae are not elevated; they are instead extended laterally and posteriorly to form, on each side, the upper enclosure of a strong, deep scrobe, in which the folded antenna can be stowed. Such strong antennal scrobes are unusual in ectatommine ants, though those of Heteroponera relicta and of some Discothyrea species (discussed above) are almost as well developed. Each frontal carina is narrowed immediately above the appropriate antennal socket. This might facilitate anterior extension

\footnotetext{
*The measurements ( $\mathrm{mm}$ ) of the Mt Gugljaband specimen are: aggregate total length 4.25; maximum head length 1.08; head width across eyes 1.02; chord length of scape 0.59 ; maximum diameter of eye 0.24 ; Weber's length of mesosoma 1.36 ; scutum width 0.82 ; petiole width 0.52 ; petiole height 0.58 ; width of postpetiole (abd. II) 0.96 .
} 
of the scapes, as is so generously accommodated in Proceratium and Discothyrea. Immediately behind this section the carina is laterally expanded and partly reflexed, to form an obtuse lobe, which appears to partially lock the scape into position when the antennae are folded (Arnoldi, Fig. 3). These modifications cause the frons and posterior parts of the clypeus to form a regularly convex, more-or-less triangular shield-like face to the cranium, a configuration not unlike that of other small cryptobiotic ants, such as some in the myrmicine tribes Dacetini and Basicerotini. The fronto-clypeal structure of Aulacopone is unlike that of any other ponerine ant, and thus immediately diagnoses the genus. The extent to which it might be associated with specialised trophic behaviour, like egg-feeding, is quite unknown. In addition the petiolar node (Figs. 3, 4), though relatively broad, is structured similarly to those of some Discothyrea females, and is quite unlike those of any Heteroponera species. The structure is somewhat like that typical of the primitive ponerine tribe Amblyoponini, and might represent a holdover from a remote amblyoponine ancestry. Abdominal segment IV is somewhat reflexed (Arnoldi, Fig. 1), though less strongly so than in Proceratium, Bradoponera or Discothyrea; or even some Heteroponera species (notably $H$. leae (Wheeler), in which segment IV is more strongly reflexed than in $A$. relicta and relatively short compared to segment III). Other descriptive details are covered by Arnoldi and illustrated in Figs. 1-4. Several points deserve further discussion. (1) The eyes are notably hairy (Figs. 1, 2). This might not be the case in workers. However, the only similar condition I have seen in tribe Ectatommini is that of a worker of an undescribed species of Heteroponera (aff. H. leae) from southwestern Western Australia. No other Australian Heteroponera has hairy eyes. (2) The scanning electron microscope has revealed an unusual structure on each pronotal humerus of the subject specimen, positioned as shown in Fig. 3. One of these structures is illustrated in detail in the stereoscopic pair of micrographs comprising Fig. 5. Each consists of a small shallow depression, without pilosity, enclosing several irregular troughs which each contain a number of minute pores. These are presumably the ducts of some previously unreported prothoracic gland. A detailed survey by steroscopic light microscope has revealed no comparable structure in any other of the several hundred ectatommine species, of all known genera, represented in the Australian National Insect Collection. 
Aulacopone thus emerges as a genus close to Heteroponera which, like Proceratium and the Bradoponera/Discothyrea line, shows adaptations to a cryptobiotic lifestyle, though these have probably been separately, and convergently evolved in the three lineages. The full degree of cryptobiotic specialisation cannot be assessed until workers of Aulacopone are collected, and checked for fronto-clypeal structure, palpal formula, mesosomal ankylosis, and relative development of the eyes, pilosity and gastral reflexion. The genus can reasonably be considered an ancient ectatommine relict, very restricted in distribution, and perhaps more readily analagous to the extinct Baltic Amber and Florissant ectatommines than to extant species. Incidentally, in addition to Bradoponera meieri and Gnamptogenys europaea, the Baltic Amber fauna includes Electroponera dubia Wheeler, which might link the Acanthoponera/Heteroponera and Ectatomma/Paraponera lineages, according to Brown. In addition I have seen, courtesy of Drs. G. D. Dlussky and A. P. Rasnitsyn, an indubitably ectatommine male from the Miocene of Kirgiziya S.S.R., in Soviet Central Asia.

The presence of these extinct or extant palearctic relicts supports Brown's view that ectatommine evolution has occurred mainly on the larger continental land masses of Eurasia, North America, and perhaps Africa; with the various lineages successively retreating, under pressure from more recently evolved groups, into the peripheral southern land areas of Australasia and South America. This model satisfactorily explains the present distribution of Gnamptogenys and the less derived and more peripheral Heteroponera, especially in the Indo-Australian area. The absence today of epigaeic ectatommines in Eurasia, Africa and much of North America is explained as a result of their past retreat under pressure from the rising subfamily Myrmicirae, which itself seems derived from an ectatommine stock, with the Baltic Amber Agroecomyrmex duisburgi Mayr providing a plausible intermediate. Proceratium and Discothyrea, unlike the epigaeic ectatommine genera, are both represented in North America, Eurasia (including Japan), and Africa, in addition to the other peripheral southern continents, where Discothyrea has its richest development. The recluse habits of these ants might explain their survival in areas which now lack, and perhaps have lost, epigaeic ectatommines. These were certainly once present in Eurasia and North America at least, as evidenced by the fossil record.

The likely cryptobiotic habits of Aulacopone relicta might also 

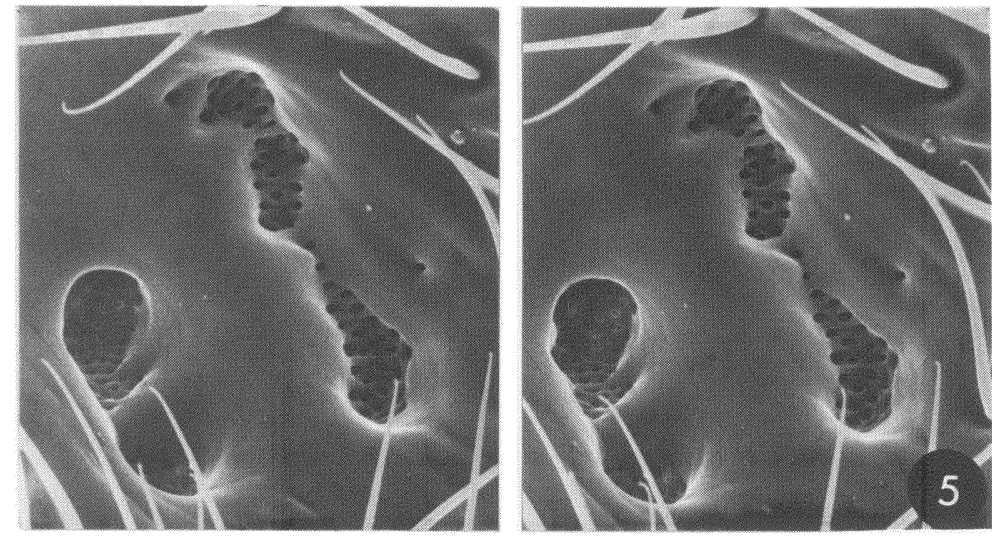

Figure 5. Aulacopone relicta, female, Mt Gugljaband, Azerbaydzhan. Details of left-hand humeral pits. Steroscopic pair, scanning electron micrographs, magnification $c a . \times 1,000$.

explain the remarkable survival of this species as an apparently rare relict in Azerbaydzhan.

Despite the circumstances of its original collection, there is little reason to suppose that $A$. relicta is a social parasite of Lasius emarginatus, although its bionomics might include cleptobiosis or lestobiosis, and the clypeal structure could be related to the latter.

The desirability of collection and study of further material of this exceptional ant provides a great challenge to Soviet myrmecology.

\section{REFERENCES}

ARNOLDI, K. V.

1930. Studien über die Systematik der Ameisen. IV. Aulacopone, eine neue Ponerinen-gattung in Russland. Zool. Anz., 89 : 139-144.

Brown, W. L. JR.

1958a. Contributions toward a reclassification of the Formicidae. II. Tribe Ectatommini (Hymenoptera). Bull. Mus. Comp. Zool. Harv., 118 : 175-362.

1958b. Predation of Arthropod eggs by the ant genera Proceratium and Discothyrea. Psyche, $64: 115$

1974. A remarkable new island isolate in the ant genus Proceratium. Psyche, 81: 70-83.

KeMPF, W. W.

1972. Catálogo abreviado das Formigas da Região Neotropical (Hymenoptera: Formicidae). Studia Ent., 15 : 3-344.

KeMPF, W. W. AND W. L. Brown, JR.

1968. Report on some Neotropical ant studies. Papéis Avulsos Zool. S. Paulo, 22 : 89-102. 

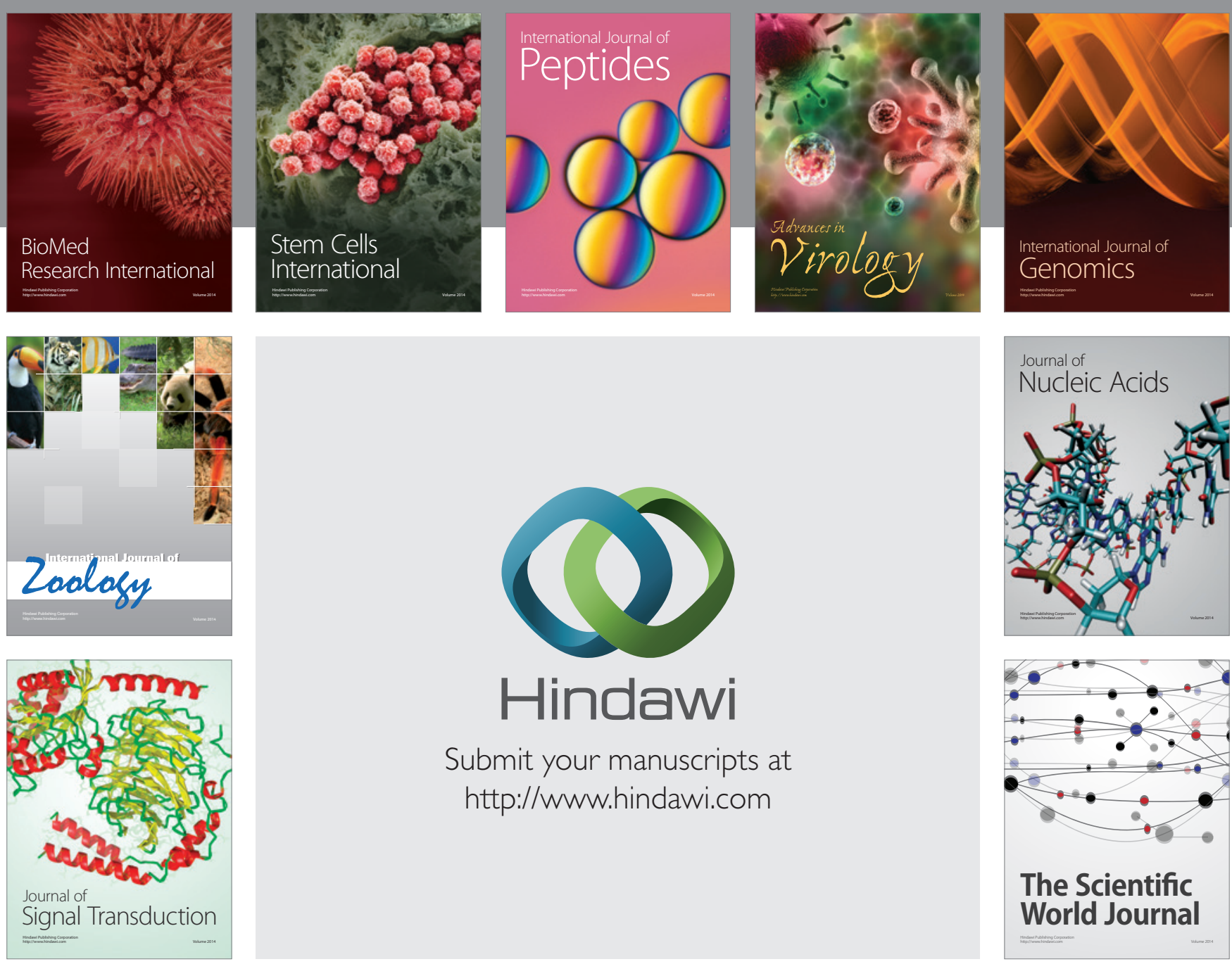

Submit your manuscripts at

http://www.hindawi.com
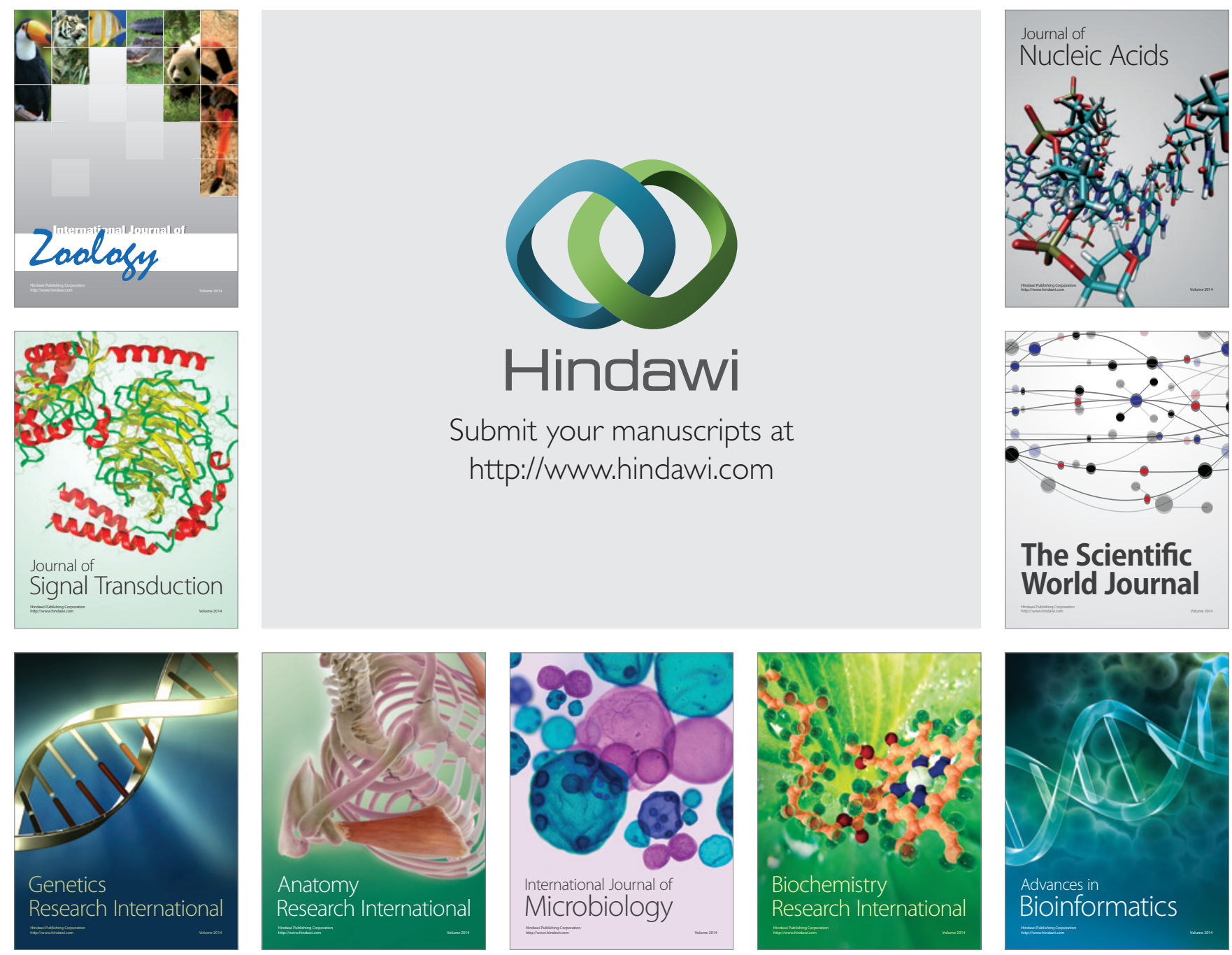

The Scientific World Journal
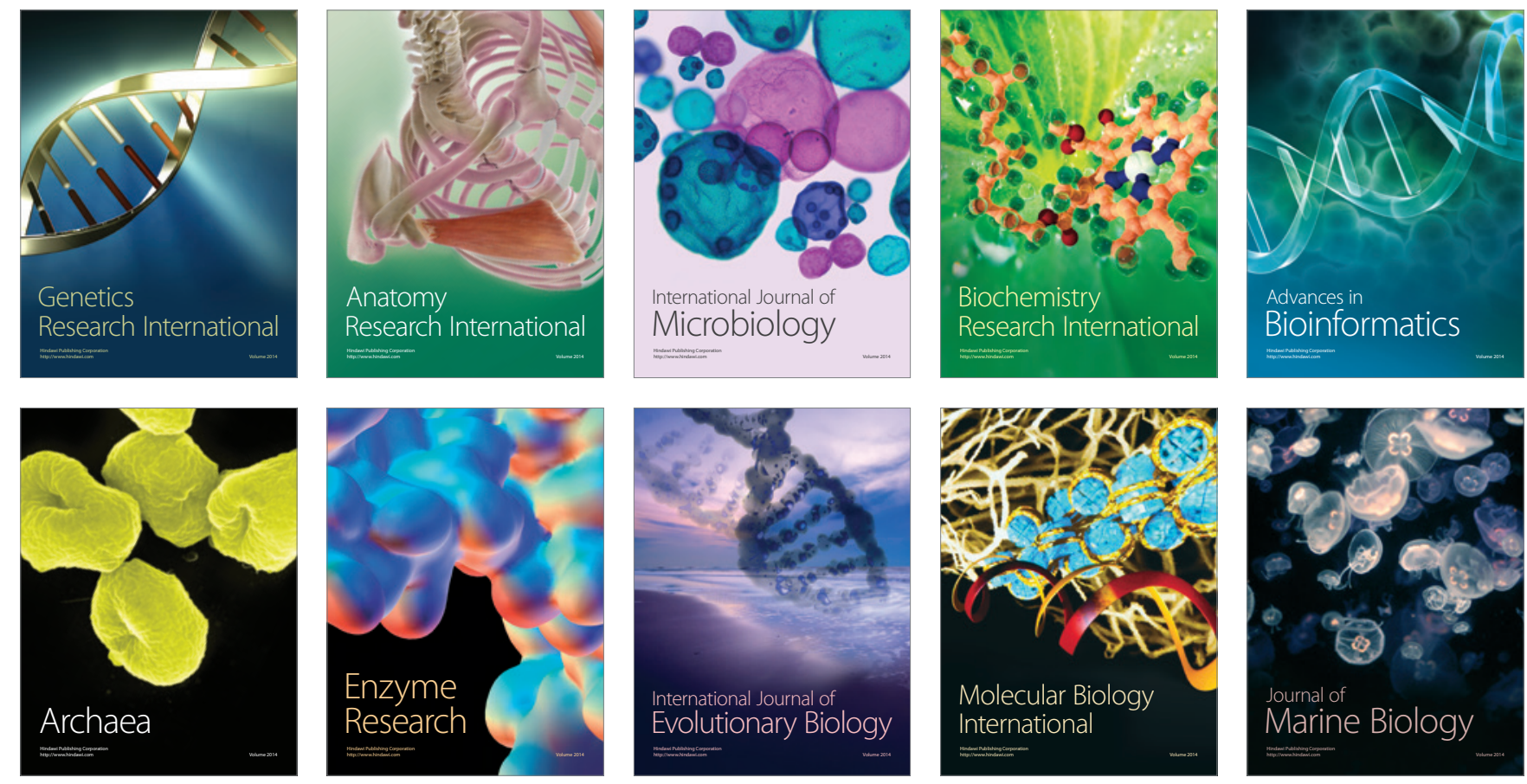